\title{
HIDROTERAPI DAPAT MENURUNKAN KADAR GULA DARAH SEWAKTU PENDERITA DIABETES MELITUS TIPE 2 DI PUSKESMAS CIPONDOH KOTA TANGERANG
}

\author{
Kusniawati, Parta Suhanda*
}

\begin{abstract}
Abstrak
Diabetes Melitus (DM) merupakan suatu penyakit kronis yang menimbulkan gangguan multisistem dan mempunyai karakteristik hiperglikemia yang disebabkan defisiensi insulin atau kerja insulin yang tidak adekuat. Upaya lain yang dapat dilakukan dalam manajemen hipergikemi adalah terapi alternatif dan komplementer/Complementary and Alternative Medicine (CAM). Salah satu terapi komplementer yang dapat dilakukan dalam manajemen hiperglikemi pada penderita DM tipe 2 adalah hidroterapi. Penelitian ini bertujuan untuk mengidentifikasi pengaruh hidroterapi terhadap kadar gula darah sewaktu penderita DM tipe 2 di Puskesmas Cipondoh Kota Tangerang. Desain penelitian quasi eksperimen dengan pendekatan control group design with pretest and posttest, teknik pengambilan sampel purposive sampling, jumlah total sampel 60 responden terdiri dari 30 responden kelompok kontrol dan 30 responden kelompok intervensi. Pengumpulan data menggunakan kuesioner dan pengukuran langsung kadar gula darah. Analisis stastistik menggunakan uji $t$ independent. Hasil analisis menunjukkan bahwa terdapat perbedaan rerata kadar gula darah sewaktu sesudah dilakukan tindakan hidroterapi pada kelompok kontrol dan kelompok intervensi $(\mathrm{p}=0.0001)$, oleh karena itu dapat disimpulkan bahwa hidroterapi dapat menurunkan kadar gula darah sewaktu pasien DM tipe 2. Hidroterapi dapat digunakan sebagai manajemen hiperglikemi pada penderita diabetes melitus.
\end{abstract}

Kata kunci: diabetes mellitus, kadar gula darah sewaktu, hidroterapi.

\begin{abstract}
Abstrack
Diabetes mellitus (DM) is a chronic disease that causes multisystem disorder and has the characteristics of hyperglycemia caused by deficiency of insulin or inadequate insulin action. Other efforts that can be done in hipergikemi management are alternative and complementary therapies/Complementary and Alternative Medicine (CAM). One of the complementary therapies that can be done in the management of hyperglycemia is hydrotherapy. This study aimed to identify the effects of hydrotherapy on blood sugar levels of patients with type 2 diabetes in Cipondoh Puskesmas Kota Tangerang. The study design was quasi experimental approach control group design with pretest and posttest, purposive sampling techniques, a total sample of 60 respondents consisting of 30 respondents control group and 30 respondents intervention group, gathering data using questionnaires and direct measurement of blood sugar levels. Statistical analysis using independent t test. The results showed that there was a difference of mean blood sugar level after hydrotherapy action in the control group and intervention group $(p=0.0001)$, therefore it can be concluded that hydrotherapy can decrease blood glucose level of DM type 2 patient. Hydrotherapy can be used as the management of hyperglycemia in patients with diabetes mellitus.
\end{abstract}

Keywords: diabetes mellitus, blood sugar level, hydrotherapy

*Dosen Jurusan Keperawatan Tangerang Poltekkes Banten 


\section{Pendahuluan}

Diabetes Melitus (DM) merupakan suatu penyakit kronis yang menimbulkan gangguan multisistem dan mempunyai karakteristik hiperglikemia yang disebabkan defisiensi insulin atau kerja insulin yang tidak adekuat. Diabetes Melitus tipe 2 merupakan DM yang tidak tergantung insulin. DM tipe 2 terjadi akibat penurunan sensitifitas insulin atau penurunan sekresi insulin (Hinkle \& Cheevar, 2014).

Organisasi Kesehatan Sedunia (WHO) memperkirakan bahwa pada tahun 2025 diperkirakan jumlah penderita Diabetes diatas 20 tahun akan meningkat menjadi 300 juta orang. Kasus diabetes akan meningkat menjadi $42 \%$ dari $51-72$ juta penduduk di negara maju dan meningkat sebesar $170 \%$ dari $84-228$ juta penduduk di negara berkembang. Angka kematian berhubungan dengan DM tipe 2 sekitar 3,2 juta dan sedikitnya satu diantara 10 kematian orang dewasa (35-64 tahun) berhubungan dengan DM tipe 2. Jumlah kasus DM di Indonesia hampir 8,5 juta orang dan merupakan negara urutan keempat untuk jumlah kasus DM setelah India, China dan Amerika Serikat (Black \& Hawk, 2009).

Manajemen diabetes bertujuan untuk mempertahankan kadar gula darah sehingga dapat meminimalkan terjadinya komplikasi akibat hiperglikemi. Manajemen diabetes membutuhkan biaya yang cukup besar sehingga bagi kelompok masyarakat ekonomi bawah hal ini merupakan masalah yang besar bagi mereka sehingga perlu difikirkan tentang upaya lain yang dapat dilakukan agar penyakitnya tetap dapat dikelola dengan baik.

Upaya lain yang dapat dilakukan dalam manajemen hipergikemi adalah terapi alternatif dan komplementer / Complementary and Alternative Medicine (CAM). Terapi komplementer diperlukan untuk melengkapi atau memperkuat pengobatan konvensional maupun biomedis agar bisa mempercepat proses penyembuhan. Salah satu terapi komplementer yang dapat dilakukan dalam manajemen hiperglikemi pada penderita DM tipe 2 adalah hidroterapi (Wike, 2007).

Hidroterapi atau terapi air putih merupakan metode perawatan dan penyembuhan dengan menggunakan air putih. Dalam hal ini perawat mendorong pasien untuk meningkatkan intake cairan secara oral dan memonitor status cairan.

Hasil penelitian Daniel dan Popkin (2010) menjelaskan bahwa dengan meminum air putih dapat mengurangi obesitas. Minum air putih sebanyakbanyaknya atau minimal enam gelas perhari akan memenuhi kebutuhan serat dan cairan. Hidroterapi dapat membantu proses pembuangan semua racun di dalam tubuh termasuk kadar gula darah yang berlebih. Hasil penelitian James (2010) menjelaskan 
bahwa dengan minum air putih menyebabkan terjadinya pemecahan gula sehingga untuk mengeluarkan zat-zat kimia melalui ginjal diperlukan jumlah cairan yang banyak. Untuk menurunkan kadar gula darah yang tepat bagi penderita DM tipe 2 adalah dengan banyak minum air hangat, banyak berolahraga dan mengurangi porsi makan (Lumbanraja, 2006).

Hasil penelitian yang dilakukan oleh Elmatris (2015) menunjukkan bahwa seluruh responden mengalami penurunan kadar gula darah sesaat setelah diberikan terapi oral dan hidroterapi. Terdapat perbedaan yang signifikan rata-rata kadar gula darah sesaat antara kelompok intervensi (pemberian terapi oral dan hidroterapi) dan kelompok kontrol (hanya pemberian terapi oral).

\section{Metode}

Desain penelitian adalah quasi eksperiment dengan pendekatan control group design with pretest and posttest. Responden pada kelompok kontrol hanya mendapatkan terapi standard sedangkan responden pada kelompok intervensi mendapatkan terapi standard dan tindakan hidroterapi. Instrumen dalam penelitian ini menggunakan kuesioner untuk mendapatkan data karakteristik responden dan lembar observasi berupa format daftar isian untuk mencatat hasil pengukuran kadar gula darah sewaktu sebelum dan sesudah dilakukan hidroterapi pada kelompok kontrol dan intervensi. Pemberian tindakan hidroterapi dilakukan selama dua minggu pada kelompok intervensi. Adapun prosedur tindakan hidroterapi dilakukan dengan cara sebagai berikut: setelah bangun tidur responden minum air putih dengan pembagian yaitu pada minggu pertama hari ke1-2 minum 2 gelas air putih, hari ke3-4 minum 4 gelas air putih dan hari ke5-7 minum 6 gelas air putih selanjutnya pada minggu kedua masing-masing minum 6 gelas air putih perhari. Penelitian ini dilakukan pada pasien Diabetes Melitus Tipe 2 di wilayah kerja Puskesmas Cipondoh untuk kelompok intervensi sedangkan kelompok kontrol pada pasien DM Tipe 2 di wilayah kerja Puskesmas Periuk Jaya Kota Tangerang. Analisis data dilakukan secara univariat dan bivariat.

Analisis univariat untuk menjelaskan variabel usia, jenis kelamin, komplikasi, riwayat keluarga DM, lama menderita DM, kadar GDS sebelum dan sesudah dilakukan intervensi pada kelompok kontrol dan intervensi. Analisis bivariat untuk mengetahui perbedaan rerata kadar gula darah sesudah dilakukan tindakan hidroterapi pada kelompok kontrol dan kelompok intervensi dengan menggunakan uji independent $t$ test. 


\section{Hasil}

\section{Analisis Univariat}

Analisis univariat dilakukan untuk menggambarkan karakteristik responden yang meliputi usia, jenis kelamin, komplikasi, riwayat keluarga DM, lama menderita DM, kadar GDS sebelum dan sesudah dilakukan intervensi pada kelompok kontrol dan intervensi. Hasil analisis univariat dijelaskan dalam tabel sebagai berikut :

Tabel 1. Distribusi responden berdasarkan Jenis kelamin, komplikasi, riwayat keluarga DM pada kelompok kontrol dan intervensi $(\mathrm{n}=30)$

\begin{tabular}{lcc}
\hline \multicolumn{1}{c}{ Variabel } & Frekuensi & $\%$ \\
\hline Kelompok kontrol & & \\
\hline Jenis kelamin & & \\
- Laki-laki & 5 & 16.7 \\
- Perempuan & 25 & 83.3 \\
\hline Komplikasi & & \\
- Ada & 4 & 13.3 \\
- Tidak ada & 26 & 86.7 \\
\hline Riwayat keluarga DM & & \\
- Ada & 8 & 26.7 \\
- Tidak ada & 22 & 73.3 \\
\hline Kelompok Intervensi : & & \\
\hline Jenis kelamin & & \\
- Laki-laki & 9 & 30 \\
- Perempuan & 21 & 70 \\
\hline Komplikasi & & \\
- Ada & 12 & 40 \\
- Tidak ada & 18 & 60 \\
\hline Riwayat keluarga DM & & \\
- Ada & 5 & 16.7 \\
- Tidak ada & 25 & 83.3 \\
\hline
\end{tabular}

Tabel 1 menunjukkan bahwa sebagian besar penderita DM tipe 2 berjenis kelamin perempuan, tidak memiliki riwayat keluarga penderita diabetes, baik pada kelompok kontrol maupun intervensi. Lebih banyak angka kejadian komplikasi pada kelompok intervensi yaitu sebesar $40 \%$ dibandingkan dengan kelompok kontrol yang hanya 13,3\%. Komplikasi yang dimaksud adalah penurunan fungsi penglihatan

Tabel. 2. Distribusi responden berdasarkan umur, lama menderita DM, kadar gula darah sewaktu pada kelompok kontrol dan intervensi $(n=30)$

\begin{tabular}{lcccc}
\hline Variabel & Mean & SD & $\begin{array}{l}\text { Minimal- } \\
\text { maksimal }\end{array}$ & $\begin{array}{l}95 \% \\
\text { CI }\end{array}$ \\
\hline \multicolumn{1}{l}{ Kelompok kontrol } & & & \\
\hline Umur & 56.20 & 10.96 & $52.11-60.29$ & 0.022 \\
\hline $\begin{array}{l}\text { ama } \\
\text { menderita }\end{array}$ & 3.00 & 1.26 & $2.53-3.47$ & 0.011 \\
\begin{tabular}{l} 
DM \\
\hline $\begin{array}{l}\text { Kadar GDS } \\
\text { sebelum } \\
\text { hidroterapi }\end{array}$
\end{tabular} & 229.37 & 78.98 & $199.87-$ & 0.002 \\
\hline $\begin{array}{l}\text { Kadar GDS } \\
\text { sesudah } \\
\text { hidroterapi }\end{array}$ & 235.50 & 63.88 & $\begin{array}{l}211.65- \\
259.35\end{array}$ & 0.001 \\
\hline
\end{tabular}

Kelompok intervensi

\begin{tabular}{|c|c|c|c|c|}
\hline Umur & 50.50 & 9.24 & $47.05-53.95$ & 0.023 \\
\hline $\begin{array}{l}\text { Lama } \\
\text { menderita } \\
\text { DM }\end{array}$ & 2.67 & 1.69 & $2.04-3.30$ & 0.000 \\
\hline $\begin{array}{l}\text { Kadar } \\
\text { GDS } \\
\text { sebelum } \\
\text { hidroterapi }\end{array}$ & 296.63 & 141.48 & $\begin{array}{l}243.8- \\
349.46\end{array}$ & 0.000 \\
\hline $\begin{array}{l}\text { Kadar } \\
\text { GDS } \\
\text { sesudah } \\
\text { hidroterapi }\end{array}$ & 221.17 & 84.68 & $\begin{array}{l}189.55- \\
252.79\end{array}$ & 0.016 \\
\hline
\end{tabular}

Tabel. 2 menunjukkan bahwa rata-rata penderita DM tipe 2 adalah berusia 50 tahunan dengan standar deviasi 10.96 dan 9.24 berturut-turut untuk kelompok kontrol dan intervensi. Umur termuda pada kelompok kontrol adalah 52.11 tahun sedangkan pada kelompok intervensi yaitu 47.05 tahun. Rata-rata lama menderita DM pada kelompok kontrol dan intervensi tidak 
berbeda jauh yaitu berada pada rentang 2-3 tahun. Rata-rata kadar gula darah sewaktu sebelum dilakukan tindakan hidroterapi pada kelompok intervensi lebih tinggi dibandingkan dengan kelompok kontrol sedangkan rata-rata kadar gula darah sewaktu sesudah dilakukan tindakan hidroterapi lebih rendah pada kelompok intervensi.

\section{Analisis Bivariat}

Analisis bivariat bertujuan untuk menganalisis perbedaan rerata kadar gula darah sewaktu pada kelompok kontrol dan intevensi sebelum dan sesudah dilakukan tindakan hidroterapi. Hasil analisis bivariat dijelaskan sebagai berikut :

Tabel. 3 Perbandingan rerata kadar gula darah sebelum dan sesudah tindakan hidroterapi pada kelompok kontrol dan intervensi $(\mathrm{n}=30)$ hidroterapi. Rata-rata kadar gula darah sesudah dilakukan hidroterapi pada kelompok kontrol adalah 235,50 mg/dl dengan standar deviasi $63,88 \mathrm{mg} / \mathrm{dl}$. Sedangkan rata-rata kadar gula darah sewaktu pada kelompok intervensi sesudah dilakukan hidroterapi adalah 221,17 mg/dl dengan standar deviasi 84.68. Hasil uji statistik menunjukkan bahwa terdapat perbedaan yang signifikan rata-rata kadar gula darah sewaktu sebelum dan sesudah hidroterapi pada kelompok intervensi $(\mathrm{p}=0,0001)$.

Tabel. 4. Perbandingan rerata kadar gula darah sewaktu sesudah dilakukan tindakan

hidroterapi pada kelompok kontrol dan intervensi

\begin{tabular}{cccccc}
\hline $\begin{array}{c}\text { Kelompo } \\
\mathrm{k}\end{array}$ & Mean & $\mathrm{SD}$ & $\mathrm{SE}$ & Pvalue & $\mathrm{N}$ \\
Intervensi & 221.1 & 84.6 & 15.4 & 0.000 & 3 \\
Kontrol & 7 & 8 & 6 & 1 & 0 \\
& 235.5 & 63.8 & 11.6 & 3 \\
& 0 & 8 & 6 & 0 \\
\hline & & & & \\
Tabel. 4 menunjukkan & bahwa rerata kadar \\
gula darah & sewaktu & sesudah & dilakukan \\
tindakan & hidroterapi & pada & kelompok \\
intervensi & adalah & 221.17 & mg/dl dengan
\end{tabular}
standar deviasi $84.68 \mathrm{mg} / \mathrm{dl}$ sedangkan untuk kelompok kontrol rerata kadar gula darah sewaktu adalah $235.50 \mathrm{mg} / \mathrm{dl}$ dengan standar deviasi $63.88 \mathrm{mg} / \mathrm{dl}$. Hasil uji statistik didapatkan nilai $\mathrm{p}=0,0001$, hal ini menunjukkan bahwa pada alpha 5\% terlihat bahwa terdapat perbedaan yang signifikan 
rerata kadar gula darah sewaktu pada pasien

DM tipe 2 sesudah dilakukan hidroterapi.

\section{Pembahasan}

Pembahasan hasil penelitian diuraikan sebagai berikut:

\section{Jenis kelamin}

Hasil penelitian ini menunjukkan bahwa lebih banyak responden yang berjenis kelamin perempuan baik pada kelompok kontrol maupun kelompok intervensi. Ligaray \& Isley (2009) menjelaskan bahwa DM tipe 2 lebih banyak dialami oleh wanita dewasa. Hal serupa juga dijelaskan oleh Tahitian (2008) bahwa klien DM tipe 2 merupakan penyakit kronis yang dapat menyerang pria maupun wanita akan tetapi dari jumlah kasus yang ditemukan di Rumah Sakit dapat diketahui bahwa angka kejadian penyakit DM tipe 2 meningkat pada wanita. Kejadian DM tipe 2 lebih sering terjadi pada perempuan dibandingkan dengan laki-laki. Hal ini dihubungkan dengan adanya faktor kegemukan (obesitas) yang merupakan faktor pencetus DM tipe 2.

\section{Umur}

Hasil penelitian menunjukkan bahwa rata-rata usia responden pada kelompok kontrol dan intervensi adalah pada rentang 50 tahunan. Hal ini dipertegas oleh $\mathrm{Xu}$ Yin (2008) yang menjelaskan bahwa dari 126 orang klien
DM tipe 2, rata-rata usianya adalah 59,6 tahun. Hasil penelitian lain yaitu Sousa et al (2009) menjelaskan bahwa dari 10 orang klien DM tipe 2 yang berada di pusat perawatan diabetes di Amerika Serikat, rata-rata berusia antara 53 tahun sampai 60 tahun. Berdasarkan beberapa hasil penelitian yang sudah dilakukan menunjukkan bahwa seseorang yang berusia diatas 40 tahun atau lansia beresiko menderita DM tipe 2 resiko, akan tetapi sumber lain menjelaskan bahwa DM tipe 2 biasanya sering terjadi pada klien setelah usia 30 tahun dan semakin sering terjadi setelah usia 40 tahun.

\section{Lama menderita DM}

Hasil penelitian ini menjelaskan bahwa rata-rata lama menderita DM yaitu antara 2.6 sampai dengan 3 tahun. Hasil penelitian ini sejalan dengan penelitian Whittemore et al (2005) yang menjelaskan bahwa rata-rata lama menderita DM adalah 2,7 tahun. Sedangkan Vivienne et al (2007) menjelaskan bahwa rata-rata lama menderita DM adalah 5,8 tahun, akan tetapi hasil penelitian ini berbeda dengan hasil penelitian Toobert et al (2000) yang menjelaskan bahwa rata-rata lama menderita DM adalah 6,3 sampai 13 tahun. 
Dalam kenyataannya bahwa lama menderita DM kurang menggambarkan kondisi penyakit yang sesungguhnya karena biasanya pasien baru terdiagnosa setelah mengalami komplikasi yang nyata padahal proses penyakit tersebut sudah berlangsung lama sebelum pasien terdiagnosa. Umumnya pasien menjelaskan lama menderita DM berdasarkan waktu saat diagnosa ditegakkan, sehingga hal ini kurang memberikan gambaran tentang lamanya menderita DM, padahal sebenarnya mungkin saja proses penyakit sudah terjadi sebelumnya

\section{Komplikasi}

Hasil penelitian ini menunjukkan bahwa hanya sebagian kecil saja dari responden yang sudah mengalami komplikasi berupa gangguan penglihatan. Hal yang harus diwaspadai bagi penderita DM adalah adanya kemungkinan komplikasi baik makrovaskuler maupun mikrovaskuler, seperti adanya ulkus diabetik, penurunan penglihatan, kelainan jantung dan ginjal. Komplikasi yang dimaksud dalam penelitian ini adalah komplikasi pada sistem penglihatan yaitu penurunan penglihatan. Sedangkan komplikasi jantung dan ginjal merupakan kriteria eksklusi dalam penelitian ini karena hal tersebut merupakan kontra indikasi untuk dilakukan hidroterapi.
5. Riwayat keluarga penderita DM

Diabetes melitus merupakan salah satu penyakit yang diturunkan secara herediter. Oleh karena itu penting bagi perawat untuk mengkaji apakah di dalam keluarga pasien terdapat riwayat keluarga penderita DM. Riwayat orang tua penderita diabetes merupakan faktor resiko seseorang menderita diabetes.

6. Pengaruh hidroterapi terhadap kadar kadar gula darah sewaktu.

Hasil penelitian ini menujukkan bahwa terdapat perbedaan yang signifikan rata-rata kadar gula darah pada kelompok intervensi sebelum dan sesudah dilakukan tindakan hidroterapi. Demikian juga dalam penelitian ini menunjukkan bahwa terdapat perbedaan yang bermakna rata-rata kadar gula darah sebelum dan sesudah dilakukan tindakan hidroterapi antara kelompok kontrol dan intervensi berdasarkan nilai selisih kadar gula darah sewaktu antara sebelum dan sesudah dilakukan tindakan hidroterapi pada kedua kelompok tersebut.

Hasil penelitian ini sejalan dengan beberapa hasil penelitian lain yang sudah dilakukan, antara lain yatu hasil penelitian Daniel dan Popkin (2010) menjelaskan bahwa dengan meminum air putih dapat mengurangi obesitas. Minum air putih sebanyak-banyaknya atau minimal enam gelas perhari akan memenuhi kebutuhan serat dan cairan. Hidroterapi dapat membantu proses pembuangan semua 
racun di dalam tubuh termasuk kadar gula darah yang berlebih. Hal tersebut diperkuat dengan hasil penelitian James (2010) menjelaskan bahwa dengan minum air putih menyebabkan terjadinya pemecahan gula sehingga untuk mengeluarkan zat-zat kimia melalui ginjal diperlukan jumlah cairan yang banyak dalam satu kali pemberian pada pagi hari. Mengkonsumsi air putih dapat membantu membuang zatzat racun di dalam tubuh termasuk gula berlebih (Sudarmoko, 2010). Hasil penelitian yang dilakukan oleh Elmatris (2015) bertujuan untuk mengetahui efek hidroterapi terhadap penurunan kadar gula darah sesaat pada penderita DM tipe 2. Metode penelitian adalah quasi eksperimen dengan pendekatan control group design with pretest and posttest, dengan total responden adalah 27 orang, 15 responden untuk kelompok control dan 12 orang kelompok intervensi. Hasil penelitian menunjukan bahwa kurang dari separuh (40\%) responden yang mengalami penurunan kadar gula darah sesaat (KGDS) setelah pemberian terapi oral, dan didapatkan semua responden (100\%) mengalami penurunan KGDS setelah diberikan terapi oral dan hidroterapi. Hasil penelitian ini menunjukkan bahwa terdapat perbedaan yang signifikan rata-rata kadar gula darah sesaat antara kelompok intervensi (pemberian terapi oral dan hidroterapi) dan kelompok kontrol (hanya pemberian terapi oral).

Penelitian lain yang dilakukan oleh Chasanah (2012) menjelaskan bahwa hidroterapi dapat mencegah terjadinya ulkus diabetikum. Hidroterapi menyebabkan terjadinya pemecahan gula yang diekskresikan melalui urin sehingga kadar gula dalam darah dapat terkontrol sehingga komplikasi ulkus diabetikum dapat dicegah.

Tindakan hidroterapi memberikan dampak positif terhadap tubuh salah satunya adalah menurunkan kadar gula darah pada penderita DM tipe 2. Hasil penelitian ini menjadi evidence base practice bagi perawat dalam melakukan tindakan keperawatan untuk mengatasi masalah keperawatan pasien.

\section{Kesimpulan}

Pada kelompok kontrol: $83.3 \%$ responden berjenis kelamin perempuan dan $16.7 \%$ berjenis kelamin laki-laki. Terdapat $86.7 \%$ responden yang tidak ada komplikasi dan $13.3 \%$ responden memiliki komplikasi. Sebanyak $73.3 \%$ responden tidak memiliki riwayat keluarga DM dan 26.7 terdapat riwayat keluarga DM, rata-rata umur responden 56,20 tahun, rata-rata lama menderita DM 3 tahun, sedangkan pada kelompok intervensi: $70 \%$ responden berjenis kelamin perempuan dan $30 \%$ berjenis kelamin laki-laki. Terdapat $60 \%$ responden yang tidak ada komplikasi dan 
40\% responden memiliki komplikasi.

Sebanyak $83.3 \%$ responden tidak memiliki riwayat keluarga DM dan 16.7 terdapat riwayat keluarga DM, rata-rata umur responden 50,50 tahun, rata-rata lama menderita DM 2.67 tahun. Rerata kadar gula darah sewaktu pada kelompok kontrol sebelum tindakan hidroterapi $229.37 \mathrm{mg} / \mathrm{dL}$ dan rerata kadar gula darah sewaktu sesudah dilakukan hidroterapi $235.50 \mathrm{mg} / \mathrm{dL}$, sedangkan rerata kadar gula darah sewaktu pada kelompok intervensi sebelum tindakan hidroterapi $296.63 \mathrm{mg} / \mathrm{dL}$ dan rerata kadar gula darah sewaktu sesudah dilakukan hidroterapi $221.17 \mathrm{mg} / \mathrm{dL}$. Terdapat perbedaan yang signifikan rerata kadar gula darah sewaktu sesudah dilakukan tindakan hidroterapi pada kelompok kontrol dan kelompok intervensi $(\mathrm{p}=0.0001)$.

\section{Saran}

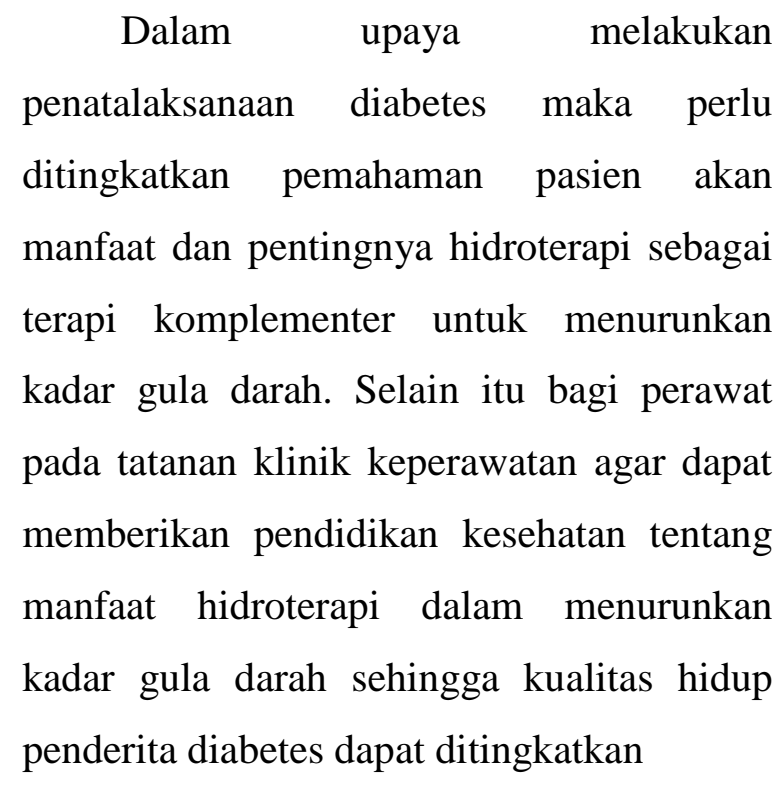

\section{Daftar Pustaka}

1. Black, J \& Hawk, J.H. 2009. Medical surgical nursing. Clinical management for positif outcomes $\left(6^{\text {th }} \mathrm{ed}\right)$. Saunders: Elsevier.

2. Brunner, L.S., \& Suddarth, D.S. 2009. Textbook of medical-surgical nursing. Lippincott : Williams \& Wilkins.

3. Chasanah. 2012. Pengaruh terapi air putih terhadap ulkus diabetikum

4. Elmatris, Afrianti Esy, Bahri Nelwati dan Yuniarti. 2015. Efek hidroterapi pada penurunan kadar gula darah sesaat terhadap penderita diabetes melitus tipe 2. Jurnal FK unand.

5. Guyton, A.C., \& Hall, J.E. 2007. Texbook of medical physiology $\left(9^{\text {th }}\right.$ ed $)$. Philadelphia : WB Saunder Company.

6. Hamad. 2007. Pengobatan penyakit dengan terapi air. Jakarta: Penerbit Aksara Qalbu

7. Hartini, S. 2009. Diabetes? : panduan lengkap untuk diabetesi, keluarganya dan profesional medis. Bandung : PT Mizan Pustaka.

8. Hinkle Janice L \& Cheevar Kerry H. 2014. Clinical Handbook for Brunner and Suddarth's. Texbook of Medical Surgical Nursing $13^{\text {th }}$ edition. Philadelphia: Lippincott Williams \& Wilkins.

9. Ignatavicius, D.D., Workman, L.M., \& Misler, A.M. (2006). Medical surgical nursing across the health care continuum $\left(3^{\text {th }}\right.$ ed). Philadelphia : W.B. Saunders Company.

10. James. 2010. How drinking water is beneficial in treating diabetes and depression. Diakses tanggal 12 April 2016 dari http://www.ygoy.com/index.php/howdrinking-water-is-benefecial-intreating-diabetes-and-depression/

11. Lumbanraja, D, 2006. Penyembuhan ajaib (edisi 2). Jakarta. Insani Jaya

12. Price, S.A., \& Wilson M.W, 2005. Patofisiologi konsep klinik prosesproses penyakit (cetakan ke-2). Jakarta: EGC. 
13. Ramaiah, S. 2006. Diabetes: Cara mengetahui gejala diabetes dan mendeteksinya sejak dini. Jakarta : Gramedia

14. Rochmah,W. 2006. Diabetes melitus pada usia lanjut, dalam Sudoyo, A.W., Setiyohadi, B., Alwi, I., Simadibrata, M., \& Setiati, S. : Buku ajar ilmu penyakit dalam (cetakan ke-3) (hlm. 1937-1940). Jakarta : Pusat Penerbit Departemen Penyakit Dalam FKUI.

15. Smeltzer, S.C., Bare, B.G., Hinkle, JL., \& Cheever, K.H. 2009. Textbook of medical-surgical nursing (1 ${ }^{\text {th }}$ ed). Philadelphia: Lippincott Williams \& Wilkins.

16. Sudarmoko. 2010. Tetap tersenyum melawan diabetes. Yogyakarta: Atma media press

17. Soegondo, S., Soewondo, P., \& Subekti, I. 2009. Penatalaksanaan diabetes melitus terpadu. Jakarta : Balai Penerbit FKUI.

18. Wike, 2007. Therapy six water glasses, diakses tanggal 12 April 2016 dari http://www.get-healthyfit.com/healthy 